\title{
SELUK BELUK REGISTRASI PENDUDUK DAN PERANANNYA DAIAM PERENCANAAN PEMBANGUNAN KEPENDUDUKAN
}

\author{
Disusun Oleh: \\ Priyono
}

\begin{abstract}
Registration of Population is source of population data. It is very important for security and population development planning. Not anly does the data cover large region (national scope) but it present continual and up to date data as well, so this data able to ful fill the need of data in time. The availability of the data and the information of population accuratelly, is absolute element in development planning. Population data from registration is used for evaluating program and it is used for analysing in longterm. Above all, it is for population development planning. Nevertheless, up to now the source of data havent been used optimally because of the lack of the quality and the completeness. The government has made effort to increase the quality of registration data so that it can be used for well fare the people.
\end{abstract}

\section{NTISARI}

Registrasi penduduk merupakan sumber data kependudukan yang sangat penting untuk tujuan keamanan dan perencanaan pembangungan kependudukan. Data ini disamping mencakup wilayab yang luas (lingkup Nasional), juga menyajikan data yang selalu baru dan kontinue sebingga dapat memenubi kebutub. an data pada suatu saat. Ketersediaan data dan informasi kependudukan yang akurat dan tepat waktu merupakan unsur mutlak dalam perencanaan pembangunan. Data penduduk dari sumber ini disamping dapat digunakan untuk mengevaluasi program-program pembangunan yang telab berjalan, juga dapat digunakan untuk analisis jangka panjang dan yang lebib penting untuk perencanaan pembangunan kependudukan. Namun demikian, bingga kini sumber data tersebut belum dapat dimanfaatkan secara optimal sebubungan dengan kendala kualitas dan kekomplitannya. Pemerintah telab berupaya meningkatkan kualitas data registrasi agar dapat dimanfaatkan untuk kesejabteraan penduduk.

\section{Pendahuluan}

Pembangunan di negara kita bertujuan untuk mewujudkan masyarakat adil dan makmur baik materiil maupun spirituil berdasarkan Pancasila. Pembangunan yang berdaya guna dan berha- sil guna selalu diawali dengan perencanaan yang didasarkan pada data atau informasi yang up to date dan valid sehingga hasilnya dapat dipertanggungjawabkan kebenarannya.

Pemerintah terus berupaya untuk memperbaiki dan menyempurnakan 
data statistik di Indonesia, sasaran pokok pengembangan perstatistikan jang. ka panjang adalah terciptanya sistem perstatistikan Nasional yang terpadu yang mampu memenuhi kebutuhan data statistik yang bermutu, tepat guna tepat waktu sebagai alat penunjang pembangunan. Tidak dapat disangkal lagi bahwa ketersediaan data dan in. formasi kependudukan yang akurat dan tepat waktu merupakan unsur mutlak dalam perencanaan dan pelaksanaan pembangunan pada umumnya dan khususnya di bidang kependudukan.

Kebutuhan data yang berskala makro masih menggantungkan sumber data kependudukan Sensus Penduduk, Survai Penduduk Antar Sensus, Survai Tenaga Kerja Nasional yang dilakukan oleh Biro Pusat Statistik. Padahal sum. ber data tersebut hanya diperoleh pada periode tertentu (10 tahun atau 5 tahun) dan kalaupun data itu tersedia, informasi yang diperoleh tidak begitu lengkap (detail) dan hanya pada tingkat administrasi propinsi atau kabupaten. Dengan demikian, baik data sensus maupun data survai, sesungguhnya hanya menggambarkan keadaan penduduk pada saat sensus atau survai itu dilaksanakan. Teknik-teknik proyeksi penduduk yang dikembangkan sering. kali sangat tergantung kepada teknik apa yang digunakan dan asumsi apa yang dipakai. Sehubungan dengan halhal tersebut di atas maka data registrasi penduduk yang dapat memberikan informasi kependudukan dari tingkat administrasi terkecil dan setiap saat menjadi sangat penting artinya dalam proses perencanaan program pembangunan.

Registrasi Penduduk sebagai suatu kegiatan yang mencatat statistik vital dilaksanakan secara terus menerus se- suai dengan terjadinya kejadian vital, sehingga data yang dihasilkannya pun dapat menggambarkan perubahan kependudukan yang terus menerus. Oleh karena itu, bila dilihat dari cakupan data yang dikumpulkan dan waktu yang digunakan maka registrasi penduduk adalah yang paling baik dan dari segi pembiayaannya pun justru yang paling murah. Namun demikian sampai saat ini kelebihan-kelebihan yang ada pada registrasi penduduk ini belum dapat dimanfaatkan sepenuhnya, atau dapat disebutkan bahwa data registrasi pen. duduk justru yang paling lemah. Bahkan bila dibandingkan dengan data hasil proyeksi pun, ketetapan data dari registrasi penduduk ini seringkali masil di bawahnya. Padahal dari aspek yuridis/landasan hukum, registrasi penduduk ini sudah mempunyai kedudukan yang jelas dan berumur cukup lama, yaitu Keppres No.52 tahun 1977, Permendagri No.8 tahun 1977 dan Permendagri No.7 tahun 1982.

Sumber data kependudukan yang terakhir ini masih memiliki banyak keterbatasan baik dalam kualitas maupun komplitnya data untuk digunakan sebagai perencanaan, untuk itu makalah ini akan membahas sumber data tersebut yang meliputi pengertian, sejarah, informasi kependudukan yang dapat diperoleh dari registrasi, keunggulan/kelemahan, peran registrasi dalam perencanaan pembangunan kependudukan dan saran penyempurnaan data registrasi.

\section{Pengertian, Sejarah dan Informasi Registrasi}

Semua sumber data kependudukan memiliki keterbatasan disamping kelebihan, begitu pula sumber data itu didapat maka konsumen akan mengeta- 
hui kualitas data yang digunakan sehingga dimana perlu pemakai data dapat melakukan penyesuaian. Hal ini tidak saja penting bagi para ahli yang melakukan analisa ilmiah, tetapi juga berguna bagi pembuat keputusan dan pejabat pemerintah atau swasta yang dalam profesinya berhubungan dengan masalah data.

Menurut konsepnya, registrasi penduduk merupakan kumpulan keterangan tentang terjadinya peristiwa yang merubah status sipil seseorang sejak dia lahir sampai meninggal (Yunus, 1981). Peristiwa itu antara lain kelahiran, kematian, datang, pergi, perkawinan, perceraian, mata pencaharian, pendidikan dan lain-lainnya. Karena registrasi mengikuti peristiwa seseorang maka tugas ini berlangsung terus menerus sehingga pencatatannya tidak begitu rumit bila dibandungkan dengan sensus penduduk.

Statistik penduduk yang didapat dari registrasi vital (kelahiran, kematian serta perpindahan) dapat memberikan petunjuk tentang arah dan laju pertumbuhan penduduk dari tahun ke tahun. Disamping itu registrasi juga dapat memberikan informasi yang baru secara terus menerus. Dari data registrasi pula dapat memberikan kemungkinan untuk melakukan analisa jangka panjang secara murah dan efektif bila dibandingkan data yang diambil dari sensus penduduk atau survai (Sofian Effensi dan Tukiran, 1989)

Berdasarkan sejarahnya, registrasi penduduk (registrasi vital) di Indonesia sudah dilakukan sejak tahun 1815 yang dikoordinir oleh Departemen Dalam Negeri. Sistem itu muncul pada masa penjajahan Inggris kemudian dalam perkembangannya dilanjutkan oleh pemerintah Belanda dengan beberapa perubahan. Kemudian tahun
1845 pemerintah kolonial Belanda melaksanakan registrasi penduduk terbatas untuk penduduk Eropa yang tinggal di Indonesia, sebagai uji coba untuk melaksanakan registrasi vital di Indonesia. Pada tahun 1929, untuk pertama kalinya pemerintah Belanda memperkenalkan registrasi vital secara menyeluruh di Yogyakarta. Dalam hal ini kepala desa diwajibkan melaporkan kejadian-kejadian kelahiran, kematian serta lahir mati disediakan formulir khusus, yang di kemudian hari dikenal dengan nama sistem triplikat yang diatur dan ditangani oleh Departemen Kesehatan (Tukiran, 1990).

Menurut sejarahnya berarti registrasi penduduk sudah dilakukan sejak la. ma dan dari waktu ke waktu selalu mengalami perubahan. Mengingat pentingnya data registrasi penduduk, pemerintah berupaya terus untuk mengadakan sistem pencatatan yang baik dan keluarnya Keppres No.52/1997 tentang pelaksanaan pendaftaran penduduk untuk mewujudkan suatu administrasi kependudukan yang berdaya guna dan berhasil guna. Untuk operasionalisasi dari Keppres tersebut dikeluarkan peraturan Mendagri No.8 1977 tentang pelaksanaan pendaftaran penduduk, Instruksi Mendagri No.X01 tahun 1977 tentang Petunjuk Pelaksanaan Pendaftaran Penduduk dan Surat Edaran Menteri Dalam Negeri No. 474.4/784/PUOD tanggal 2 Maret 1992 perihal Pengelolaan Pemberian Kartu Tanda Penduduk dan Petunjuk Pelaksanaan Pengisiannya. Berkenaan dengan keluarnya Keppres dan Peraturan Mendagri menunjukkan betapa besar perhatian Pemerintah dalam meningkatkan administrasi kependudukan di Indonesia.

Sejalan dengan ketentuan dalam Keputusan Presiden No.52 Tahun 1977 
dan berbagai peraturan pelaksanaannya tentang Pendaftaran Penduduk, Pemerintah Daerah melalui aparat-aparat pelaksana di daerahnya dituntut agar dalam pelaksanaan registrasi Penduduk, diarahkan kepada suatu sistem yang penanganannya dapat dilakukan secara terus menerus, cermat, tepat dan dapat disajikan data yang mutakhir serta dapat memilah dengan baik antara warga negara Indonesia (WNI) dan warga negara asing (WNA) yang merupakan penduduk tetap atau pendatang sementara (Alwi Dahlan, 1990). Registrasi Penduduk pada hakekatnya menyangkut berbagai aspek kehidupan dan kepentingan yang bersangkutan antara lain:

- Aspek Identitas Diri

- Aspek Status Kewarganegaraan

- Aspek Mobilitas Penduduk

- Aspek Ketenagakerjaan dan lainlain

- Aspek Perencanaan Program Pembangunan Nasional dan Daerah

- Aspek Pendapatan Nasional

- Aspek Ketentraman dan Ketertiban

Registrasi Penduduk tidak hanya berorientasi pada masalah identitas, kewarganegaraan, ketentraman dan ketertiban saja, tetapi justru mempunyai berbagai aspek kepentingan yang diperlukan sesuai dengan kebutuhannya, terutama untuk pembangunan. Perlu disadari bahwa dalam praktek telah banyak penduduk yang berstatus Orang Asing ingin segera menjadi Warga Negara Indonesia melalui berbagai jalan pintas seperti pemalsuan Surat Bukti Kewarganegaraan Republik Indonesia (SKBRI) dan bahkan melalui Kartu Tanda Penduduk (KTP) yang tidak sah.

Tugas pencacatan dan pelaporan penduduk menurut Keppres No.52/1977 sebagai berikut:
1. Pencatatan yang dilakukan di desa/kalurahan:

a. Kejadian kelahiran, kematian dan lahir mati dengan memakai triplikat, bagian kiri triplikat untuk asrip desa/kalurahan, bagian tengah dikirimkan ke Kecamatan dan bagian sebelah kanan untuk disimpan yang bersangkutan/kepala keluarga.

b. Keterangan pindah, dibuat rangkap tiga. lembar pertama untuk yang bersangkutan, lembar kedua dikirimkan ke Kecamatan dan lembar ketiga disimpan sebagai arsip desa/kalurahan.

c. Kartu keluarga dibuat rangkap 4 (empat), dengan penjelasan sebagai berikut:

Lembar :

I. Untuk kepala keluarga

II. Untuk RT

III. Untuk RK/RW dan

IV. Untuk Desa/Kalurahan

d. Buku Mutasi dipergunakan di desa/kalurahan untuk mencatat jumlah kelahiran, kematian dan perpindahan selama satu bulan.

e. Buku Induk dipergunakan untuk mencatat keadaan penduduk pada awal pencatatan dan pada pencatatan selanjutnya, dirubah sesuai mutasi (perubahan) yang terjadi.

f. Laporan bulanan desa/kalurahan dipergunakan untuk mencatat jumlah penduduk serta perubahan yang terjadi selama sebulan karena mutasi. Yaitu jumlah penduduk awal bulan, jumlah kelahiran, kematian dan perpindahan serta jumlah penduduk akhir bulan. Dibuat rangkap dua, lembar pertama dikirimkan ke Kecamatan dan lem. 
bar kedua disimpan sebagai arsip desa/kalurahan.

2. Di Tingkat Kecamatan:

a. Triplikat kelahiran, kematian dan lahir mati bagian tengah yang diterima dari desa/kalurahan sebagai bahan untuk mengadakan pengecekan laporan bulanan desa/kalurahan.

b. Keterangan pindah yang diterima dari desa/kalurahan (tembusan, lembar kedua).

c. Kartu keluarga yang diterima dari desa/kalurahan (tembusan/lembar keempat)

d. Laporan bulanan desa/kalurahan

e. Laporan Kependudukan bulanan yang dibuat di Kecamatan berdasarkan rekap dari laporan bulanan desa/kalurahan. Laporan ini dibuat rangkap dua. Satu dikirim ke Kabupaten/Kotamadya Daerah Tingkat II dan satu lagi disimpan sebagai arsip kecamatan.

f. Kartu Tanda Penduduk (KTP) diberikan oleh Camat atas nama Bupati/Walikotamadya Kepala Daerah Tingkat II pada setiap penduduk yang telah berusia 17 tahun atau yang telah kawin atau pernah kawin. Berlaku selama dua tahun.

3. Di Tingkat Kabupaten/Kotamadya Daerah Tingkat II:

a. Laporan Kependudukan bulanan yang dikirimkan oleh Kecamatan setelah diadakan pengecekan seperlunya.

b. Dibuat laporan kependudukan bulanan per kabupaten/Kotamadya daerah Tingkat II rangkap dua berdasarkan rekap dari laporan kependudukan bulanan dari kecamatan. Satu rangkap dikirimkan ke Propinsi dan satu rangkap lagi, disimpan sebagai arsip Kabupaten/Kotamadya daerah Tingkat II.

\section{ARUS LAPORAN DATA REGISTRASI PENDUDUK \\ (KEPPRES NO.52/1977)}

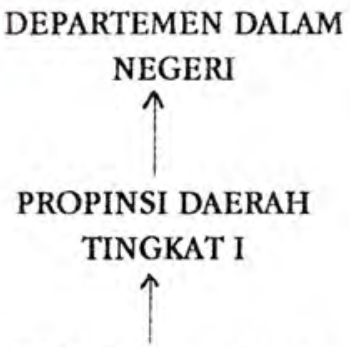

KABUPATEN/KOTA-

MADYA DAERAH

TINGKAT II
Laporan Kependudukan seluruh Propinsi Daerah Tingkat I

Laporan Kependudukan seluruh Kabupaten/Kotamadya Daerah Tingkat II

1. Laporan Kependudukan Kabupaten/Kotamadya Dati II (dibuat oleh Kabupaten/Kotamadya Daerah Tingkat II)

2. Laporan Kependudukan Kecamatan 


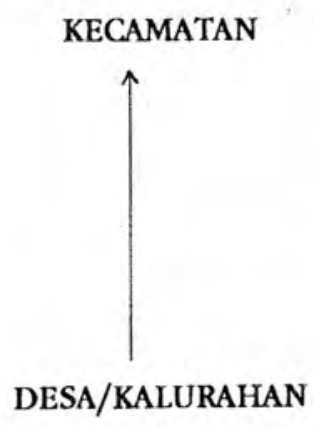

1. Triplikat kelahiran, kematian dan lahir mati

2. Keterangan pindah

3. Kartu keluarga

4. Laporan bulanan desa

5. Laporan kependudukan (dibuat oleh kecamatan)

6. KTP (dibuat oleh kecamatan untuk penduduk berumur 17 tahun atau telah kawin)

1. Arsip triplikat kelahiran, kematian, lahir mati dan migrasi

2. Keterangan pindah

3. kartu keluarga

4. Buku Mutasi

5. Buku Induk

6. Laporan Bulanan Desa/Kalurahan

INFORMASI KEPENDUDUKAN DALAM REGISTRASI VITAL

Informasi Kartu Keluarga

1. Jumlah jiwa

2. Jenis kelamin

3. Hubungan dengan Kep.Kel

4. Tgl; bulan, tahun lahir

5. Tempat lahir

6. Propinsi

7. Status Perkawinan

8. Agama

9. Kewarganegaraan

10. Pendidikan terakhir

11. Kemampuan membaca/menulis

12. Pekerjaan

13. Tgl, bl, th. mulai tinggal

14. Kepindahan dari

\section{Surat Kelahiran}

1. Jenis kelamin

2. Tgl, bl, tahun lahir

3. Kelahiran

4. Tempat kelahiran

5. Penolong kelahiran

6. Tgl, bl, th, lahir ibunya
7. Kewarganegaraan ibu

8. Tgl, bl, th, lahir bapaknya

\section{Surat Lahir Mati}

1. Lama dalam kandungan

2. Jenis kelamin

3. Tgl, Bln, Tahun lahir

4. Kelahiran

5. Tempat lahir

6. Penolong kelahiran

7. Cara penguburan

8. Tgl, Bln, Tahun lahir ibunya

9. Kewarganegaraan

10. Tgl, Bln, Tahun lahir bapak

11. Kewarganegaraan

12. Pekerjaan

Surat Kematian

1. Jenis Kelamin

2. Tempat tinggal

3. Tgl, Bln, Tahun lahir

4. Tgl, Bln, Tahun meninggal

5. Umur meninggal (hari, bln, Th.)

6. Kewarganegaraan

7. Agama

8. Status perkawinan 
9. Pekerjaan

10. Tempat meninggal

11. Sebab meninggal

12. Yang menentukan: variasi

\section{Surat Pindah}

1. Jenis kelamin

2. Tanggal bulan tahun lahir

3. Kewarganegaraan

4. Agama

5. Status Perkawinan

6. Pekerjaan

7. Pendidikan

8. Daerah asal

9. Daerah tujuan

10. Tanggal bulan tahun pindah

11. Alasan pindah

12. Jumlah yang ikut pindah

13. Jenis kelamin yg. ikut pindah

14. Umur yang ikut pindah

15. Status perkawinan yang ikut pindah

16. Pendidikan yang ikut pindah

Sistem Pengambilan Keputusan

Bidang Kependudukan

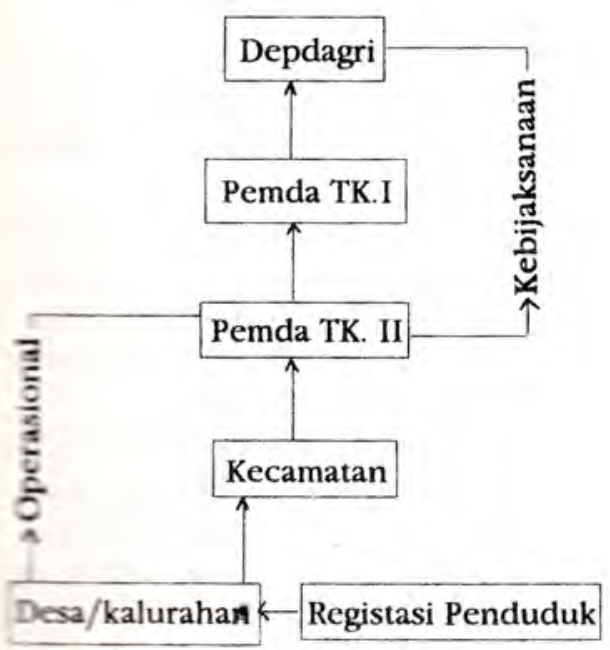

Kelebihan, Kelemahan dan Manfaat Registrasi Penduduk

Ada beberapa kelebihan data registrasi penduduk dibanding sumber data kependudukan yang lain antara lain:

1. Memberikan informasi kependudukan dari wilayah administrasi terkecil (Dukuh/RT)

2. Memberikan informasi kependudukan setiap saat dan terus menerus

3. Mengetahui perubahan penduduk dan prospeknya di masa datang secara cepat dan relatif akurat.

4. Prosedur pencatatannya tidak terlalu rumit dibanding dengan sensus dan survei karena dilakukan secara terus menerus.

5. Tidak banyak memakan biaya dan pemikiran yang ruwet karena sudah merupakan kegiatan rutin.

Meskipun memiliki beberapa kelebihan dan telah ditunjang Keppres No.52 Tahun 1977 akan tetapi sampai saat ini Pemerintah menggunakan ukuran-ukuran demografi seperti tingkat kelahiran, tingkat kematian, jumlah penduduk dari hasil estimasi dengan teknik demografi tertentu. Hal ini disebabkan karena kegiatan registrasi penduduk belum dapat berfungsi sebagaimana mestinya sehingga data yang tercermin masih kurang komplit dan kurang valid.

Keterbatasan atau kelemahan data registrasi penduduk dapat dikelompokkan menjadi tiga bagian yakni bersumber pada pencatatannya, bersumber pada pengolahan pelaporan dan bersumber kepada sistem atau mekanisme kerja yang belum tepat (Alwi Dahlan, 1990). 


\section{Kelemahan Data Registrasi}

1. Data registrasi penduduk lebih banyak memberikan informasi yang berkaitan dengan keamanan dibanding untuk perencanaan pembangunan secara keselurihan. Hal ini bisa diperkuat dengan penelitian Kasto (1974) bahwa sebagian besar kepala desa menjawab akan memberikan jawaban untuk kepentingan keamanan terhadap pertanyaan kegunaan statistik penduduk.

2. Data registrasi penduduk di tingkat bawah ditangani oleh orang- orang yang relatif rendah pendidikannya sehingga mereka belum banyak mengetahui manfaat data registrasi penduduk.

3. Belum adanya keseragaman atau penyatubahasaan konsep-konsep kependudukan seperti lahir hidup, lahir mati, umur dan sebagainya.

4. Rendahnya partisipasi masyarakat untuk memberikan informasi kependudukan. Keengganan ini bisa berkaitan dengan ketidaktahuan ataupun aspek sejarah.

5. Belum adanya sangsi-sangsi yang tegas kepada mereka yang tidak mela. porkan kejadian demografi.

6. Belum dibudidayakan penggunaan kartu kelahiran, kematian, perpindahan untuk pelbagai keperluan misalnya untuk berobat, mencari surat keterangan tertentu, pajak dan lain-lainnya.

7. Pengolahan dan pelaporan data registrasi belum ditangani dengan serius karena petugas lebih tertarik pada urusan yang dapat menghasilkan uang (bersifat material) sedang urusan registrasi tidak ada apa-apanya.

8. Mekanisme kerja antara isntansi di tingkat bawah sampai atas belum terkoordinir dengan baik.
9. Biro Pusat Statistik tidak punya bawahan sampai ke tingkat desa, padahal BPS adalah gudangnya data kependudukan dan merupakan lembaga non departemen yang diserahi tugas untuk menyediakan data.

Manfaat Data Registrasi Penduduk

- Pemanfaatan Data Kelahiran

1. Jenis kelamin: untuk mengetahui rasio kelahiran bayi laki-laki terhadap perempuan

2. Dilahirkan tanggal/bulan/tahun: untuk mengetahui distribusi kelahiran dan umur.

3. Kelahiran, tunggal/kembar (jika kembar, kelahiran ke berapa) dapat digunakan untuk mengetahui urutan kelahiran (dalam hubungannya dengan $\mathrm{KB}$ )

4. Tempat kelahiran dan penolong kelahiran digunakan untuk mengetahui distribusi layanan kesehatan.

5. Identitas ibu dan bapak digunakan untuk mengetahui umur pada saat melahirkan terutama umur ibu, apakah kelahiran anak I pada umur muda/tua.

- Pemanfaatan Data Kematian

1. Jenis kelamin: untuk mengetahui pola kematian menurut jenis kelamin (pria wanita)

2. Dilahirkan: tanggal, bulan, tahun; meninggal, tanggal, bulan, tahun; umur saat meninggal untuk mengetahui distribusi kematian menurut umur.

3. Status perkawinan; digunakan untuk mengetahui adakah perbedaan kematian menurut status perkawinan (apakah perkawinan seseorang mempengaruhi kematian)

4. 
Sebab kematian; untuk analisa mortalitas dan morbiditas

5. Yang menentukan; untuk mengetahui kualitas data sebab kematian dan distribusi layanan kesehatan.

- Pemanfaatan Data Migrasi

1. Jenis kelamin

2. Tanggal/bulan/tahun/umur

3. Status perkawinan

4. Pekerjaan

5. Pendidikan

6. Pengikut

7. Daerah asal

8. Daerah tujuan

9. Alasan pindah

Apakah telah terjadi migrasi selektif (laki-laki berumur muda, relatif berpendidikan, dan bujangan atau telah terjadi perpindahan keluarga (pengikut) pada umur menegah berpendidikan rendah. Mengetahui arus migrasi desa/kota/antar kabupaten/propinsi.

- Pemanfaatan Buku Induk dan Buku Mutasi

1. Buku Induk digunakan untuk mencatat seluruh penduduk dalam desa

2. Buku Mutasi digunakan untuk mencatat seluruh kejadian pokok selama satu bulan.

\section{- Laporan Bulanan Desa}

Laporan bulanan desa memuat keterangan perkembangan penduduk selama sebulan. Dibuat sekali sebulan dan dikirim ke Kecamatan bersama surat kelahiran, kematian dan pindah.

\section{- Kartu Keluarga}

Kartu Keluarga digunakan untuk mencatat karakteristik kepala keluarga an anggotanya pada saat kartu itu dibuat.
Perananan Registrasi dalam Pembangunan Kependudukan

1. Komposisi penduduk menurut umur dan jenis kelamin

1.1 Data ini amat penting untuk perencanaan di bidang pendidikan karena dengan data tersebut kita dapat mengetahui berapa jumlah anak-anak yang memasuki sekolah SD, SLTP, SLTA dan seterusnya. Bila kita tahu jumlahnya, maka kira-kira berapa lokal sekolah, jumlah guru, jumlah karyawan, penjaga, satpam dan lain-lain, yang harus ditambah untuk dapat menampung mereka, sehingga mereka yang termasuk usia sekolah baik SD, SLTP, SLTA dan seterusnya betul-betul dapat menikmati sekolah. Nyatalah bahwa data komposisi penduduk menurut umur dan jenis kelamin tampil di depan dalam perencanaan pendidikan. Untuk melaksanakan wajib belajar memerlukan perhitungan secara demografi jumlah dan komposisi penduduk yang berkepentingan. Tahukah kita agar supaya agak tepat bagi tiap-tiap daerah kuantitas dan kualitas anak-anak terperinci menurut umur dan jenis kelamin yang harus dilayani dalam rangka wajib belajar.

1.2Data ini dapat mengetahui jumlah tenaga kerja yang tersedia suatu daerah. Kita tahu bahwa tenaga kerja merupakan sumber daya manusia yang dapat menunjang pembangunan. Suatu kenyataan di daerah pedesaan tertentu mencari tenaga kerja untuk mengolah tanah pertanian sudah sulit karena mereka ke- 
banyakan lari ke kota untuk mendapatkan upah yang lebih tinggi. Di luar Jawa sumber daya alam relatif melimpah dan sebaliknya sumber daya manusia (tenaga kerja) masih kurang sehingga masih banyak diperlukan untuk dapat memanfaatkan sumber daya alam untuk kesejahteraan manusia. Jadi data ini amat berguna bagi kebijaksanaan ke. tenagakerjaan dan transmigrasi.

1.3Data ini dapat mengetahui kecenderungan pertambahan penduduk. Hal ini dapat dicirikan dari bentuk piramida penduduk. Bentuk piramida yang lebar di bawah menunjukkan pertum. buhan penduduk tinggi atau proporsi anak termasuk tinggi. Jika kita mempunyai data ini maka kebijaksanaan tentang penurunan fertilitas segera diambil, kalau ingin merubah bentuk piramida pada masa yang akan datang.

Komposisi penduduk muda mempunyai efek:

a. Kebutuhan pangan akan meningkat sehubungan dengan perkembangan fisik mereka.

b. Fasilitas pendidikan yang makin meluas dibutuhkan untuk menampung meningkatnya orang membutuhkan pendidikan. Hal ini menghambat usaha peningkatan suatu pendidikan.

c. Arus pencari kerja baru lebih banyak terdiri dari tenaga muda yang walaupun berpendidikan, tetapi masih belum berpengalaman. Piramida penduduk yang lebar di bawah dapat dianggap akan lebih mendorong tingkat konsumsi ke atas menekan tingkat tabungan ke bawah sehingga dapat dikatakan bahwa faktor demografi turut mempengaruhi usaha pembentukan modal yang diperlukan untuk investasi.

1.4Dapat dipakai untuk menentukan dependency ratio (beban ketergantungan). Suatu daerah memiliki beban ketergantungan tinggi bila proporsi keduanya relatif rendah. Negara berkembang kebanyakan memiliki beban angka ketergantungan tinggi, sebaliknya negara maju memiliki beban ketergantungan rendah. Berdasarkan SP 1971 dan 1980 beban ketergantungan di Jawa Tengah sebagai berikut:

DR Jawa Tengah $1971=\mathbf{8 5 , 7 8 \%}$

DR Jawa Tengah $1980=78,48 \%$

2. Komposisi penduduk menurut mata pencaharian

Dari data bisa diketahui struktur ekonomi suatu daerah. Struktur ekonomi pertanian, industri, jasa maupun lain-lain. Struktur ekonomi inciustri akan lebih banyak menyerap tenaga kerja dibanding pertanian dan sektor ini membutuhkan skill. Pendapatan di sektor ini biasanya lebih tinggi. Di lain pihak sektor industri bisa mencemarkan udara maupun air. Oleh karena itu memerlukan perencanaan yang matang untuk mengurangi efek negatif.

3. Komposisi penduduk menurut pendidikan

Data ini dapat memberikan gambaran kepada kita berapa jumlah penduduk yang buta huruf, penduduk yang tamat SD, SMP, SMA, PT dan seterusnya. Dus memberikan informasi mengenai kemajuan pendudukan dan kualitas penduduk. Dalam kaitannya dengan pembangunan, dalam hal ini pemberantasan buta huruf, maka data ini amat berperan. Oleh sebab itu amat 
penting dalam kebijaksanaan pen- kota

didikan.

4. Komposisi penduduk menurut perkawinan

Disamping merupakan kewajiban, perkawinan bertujuan memperoleh keturunan. Angka proporsi yang tinggi dari mereka yang kawin memberi petunjuk kepada kita tentang tingginya fertilitas (terutama pada pasangan usia subur). Seperti kita ketahui pasangan usia subur (Eligable couple) merupakan sasaran keluarga berencana, sehingga kalau mereka bisa terjaring kemungkinan penurunan fertilitas dapat dicapai.

Dari komposisi ini pula kita dapat mengetahui jumlah penduduk yang cerai, duda, janda dan lain-lain. Hal ini memerlukan interpretasi dalam kaitannya dengan pertumbuhan penduđuk suatu daerah.

\section{Penggunaan lahan}

Data monografi statis yang menyajikan tata guna lahan memberikan gambaran kepada kita tentang berapa proporsi luas tanah suatu daerah digunakan untuk sawah, industri, bangunan rumah dan lain-lain. Apabila perubahannya diikuti dengan cermat maka kita bisa mengetahui berapa besar perubahan lahan sawah menjadi lahan dengan tata guna tanah lain atau sebaliknya tata guna tanah lain menjadi sawah. Sehingga dapat diperkirakan berapa ton bahan makan bertambah/berkurang setiap tahunnya.

Seperti kita ketahui bahwa daerah pedesaan merupakan daerah supply bahan makan bagi daerah kota. Penyusutan lahạn pertanian di daerah pedesaan tentunya akan berpengaruh terhadap keseimbangan hubungan desa

6. Pencatatan kelahiran, kematian, datang dan pergi

Perubahan penduduk suatu daerah dipengaruhi oleh variabel yaitu kelahiran, kematian, datang dan pergi. Dalam demografi, secara sistematis dapat dilukiskan dalam persamaan berimbang.

$\mathrm{Pt}=\mathrm{Po}+(\mathrm{Ke}-\mathrm{Km})+(\mathrm{D}-\mathrm{P})$

$\mathrm{Pt}=$ Jumlah pada waktu 1 tahun

Po $=$ Jumlah penduduk awal

$\mathrm{Ke}=$ Kelahiran selama periode $\mathrm{t}$

$\mathrm{Km}=$ Kematian selama periode $\mathrm{t}$

$\mathrm{D}=$ Jumlah pendatang selama periode $t$

$\mathrm{P}=$ Jumlah yang pergi selama periode $t$

Pencatatan kelahiran secara baik memberikan kepada kita tentang kemungkinan pertumbuhan penduduk pada suatu daerah dan darinya dapat diteliti kira-kira faktor-faktor apakah yang menyebabkan (fertilitas tinggi/rendah). Di sini kita sampai pada usaha penyebarluasan keluarga berencana atau malah kebijaksanaan pro natalis. Demikian juga pencatatan yang terperinci mulai dari bayi, anak dan dewasa adalah informasi yang sangat berguna. Pencatatan kematian disamping penting bagi kebijaksanaan di bidang kesehatan, ia juga dapat mengevaluasi seberapa jauh suatu program dapat dilaksanakan. Pencatatan mengenai pristiwa kematian yang diikuti dengan sebab-sebab kematian serta tempat terjadinya (desa/kota) adalah perlu sekali karena kita dapat mengetahui prosentase terbesar dari kematian disebabkan oleh apa dan bagaimana perbedaan antara kota dan desa.

Demikian juga pencatatan mengenai jumlah pendatang dan jumlah yang pergi perlu dilakukan, disamping un- 
tuk mengetahui pengaruhnya terhadap pembangunan daerah, problem dan keinginan yang ditimbulkan/dibutuhkan mereka, terutama di kota-kota besar, informasi ini sangat diperlukan dalam perencanaan tata kota dan pusatpusat pelayanan insklusif di dalamnya. Kita sering mendengar keluhan kota besar atas ketidakmampuan menampung derasnya arus migran. Di negara kita tampaknya tidak mungkin melarang penduduk pindah tempat, kecuali bila dihadapkan pertambahan penduduk yang sudah mencemaskan.

Jelaslah bawa peristiwa-peristiwa vital seperti tersebut di atas sangat baik untuk dimonitoring, disamping sebagai sumber data dan mengetahui keadaan peristiwa suatu daerah, tetapi seklaigus merupakan alat penilaian terhadap program keluarga berencana, program kesehatan (penurunan kematian baik bayi, anak dan dewasa) dan program penyebaran penduduk.

\section{Jumlah penduduk, luas daerah}

Untuk mengetahui kepadatan penduduk suatu daerah diperlukan data tentang jumlah penduduk dan luas daerah. Angka ini penting bagi penyusunan kebijaksanaan dalam hal pelayanan baik di bidang kesehatan, pendidikan, pelayanan perkantoran. Seperti apa yang pernah diberitakan di surat kabar kebutuhan pegawai/drop pegawai di kantor kecamatan/kalurahan akan ditentukan oleh banyaknya masyarakat yang dilayani, luas daerah dan beban tugas. Lebih-lebih sekarang ada pengaturan baru masalah tanah untuk keperluan pembangunan.

\section{Saran Penyempurnaan}

1. Agar dipisahkan daerah (misalkan orang yang mondok harus mempu- nyai KTP) informasi kependudukan yang bertujuan untuk keamanan dan bertujuan untuk perencanaan kependudukan sehingga pengguna data akan lebih mudah memanfaatkannya (termasuk menelusuri).

2. Diperlukan tenaga dari Biro Pusat Statistik yang diterjunkan di desa untuk menangani data registrasi penduduk. Tenaga ini bertanggung jawab penuh terhadap pengumpulan dari data registrasi penduduk di tingkat desa. Tenaga tersebut harus memiliki pengetahuan tentang statistik, minimal lulusan SLTA.

3. Surat kelahiran, kematian dan surat pindah agar digunakan sebagai syarat untuk urusan-urusan penting misalnya untuk masuk sekolah, berobat dan lain-lain sehingga ada semacam keharusan untuk memilikinya.

4. Meningkatkan kesadaran masyarakat akan pentinya data registrasi penduduk baik lewat jalur formal misalnya pendidikan maupun jalur informal.

5. Peningkatan koordinasi antara petugas mulai tingkat desa sampai ke tingkat pusat sehingga bila terjadi permasalahan dan ketidaksinkronisan segera dapat dipecakan

6. Dukungan logistic untuk registrasi penduduk harus diperhatikan, jangan sampai terjadi blangko registrasi habis.

7. Dataregistrasi penduduk secara rutin perlu dilombakan antar desa, dengan penilaian dari segi kualitas data, kekomplitan, dan penyajian dalam tabel. Langkah ini merupakan salah satu upaya peningkatan data registrasi penduduk. 


\section{Kesimpulan}

Registrasi penduduk merupakan sumber data yang dapat memberikan informasi sesuai dengan saat kejadian sehingga data yang dihasilnya pun dapat menggambarkan perubahan penduduk secara terus menerus. Oleh karena itu, bila dilihat dari cakupan data dan waktu yang digunakan maka registrasi penduduk adalah sumber data yang paling baik dan dari segi pembeayaan justru paling murah. $\mathrm{Na}$ mun demikian, kualitas data ini belum dapat dijamin kebenarannya karena angka-angka yang dihasilkan memberikan angka lebih atau bahkan kurang dari keadaan sebenarnya. Untuk menanggulangi kelemahan ini biasa digunakan perkirakan tidak langsung dari sumber data Sensus Penduduk sehingga kebutuhan data dapat terpenuhi.

Data registrasi disamping memiliki kelebihan, juga tidak luput dari keter- batasan. Kelebihan data ini dapat memberikan informasi kependudukan dari wilayaj administrasi terkecil setiap saat serta terus menerus, mengetahui perubahan penduduk dan prospeknya di masa datang secara cepat dan akurat, prosedur pencatatannya tidak terlalu rumit dan beaya relatif murah. Kelemahan data registrasi terletak pada aspek produsen dan konsumen, masalah managemen dan koordinasi. Disamping itu aspek yang penting lagi adalah pembudayaan manfaat registrasi penduduk bagi pengelola maupun konisumen, yang selama ini masih menjadi kendala. Yang dimaksud pengelola adalah aparat desa yang langsung menangani registrasi, sedang konsumen adalah masyarakat yang memberi informasi. Upaya perbaikan telah dilaksanakan oleh Pemerintah agar data registrasi penduduk dapat dimanfaatkan untuk perencanaan pembangunan di bidang kependudukan.

\section{DAFTAR PUSKATA}

Awi Dahlan, 1990. Butir-butir sambutn ASMEN I KLH. Sambutan disampaikan pada Pelatihan Registrasi Penduduk, Yogyakarta 18-20 Januari 1990.

Yunus, 1981. Sumber data kependudukan, dalam buku Dasar-dasar Demografi, Lembaga Demografi, Fakultas Ekonomi, Universitas Indonesia.

Kasto, 1974. Registrasi Penduduk di Daerah Istimewa Yogyakarta, Majalah Demografi Indonesia, 2(1): 134-161.

Sofian Effendi dan Tukiran, 1989. Sumber data kependudukan dan pentingnya data penduduk. Makalah ini disampaikan dalam Job training administrasi kependudukan angkatan V, Jakarta 6-9 Desember 1989. 